\title{
Effects of Ligand Priming and Multiple-Dose Injection on Tissue Uptake of ${ }^{111}$ In-Pentetreotide in Rats
}

\author{
Wout A. P. Breeman, * Marion de Jong, Bert F. Bernard, Willem H. Bakker, \\ Edgar J. Rolleman, Dik J. Kwekkeboom, Theo J. Visser and Eric P. Krenning \\ DEPARTMENTS OF NUCLEAR MEDICINE AND INTERNAL MEDICINE III, UNIVERSITY HOSPITAL "DIJKZIGT," \\ ROTTERDAM, THE NETHERLANDS
}

\begin{abstract}
In patients undergoing somatostatin receptor scintigraphy, treatment with octreotide (Sandostatin $\left.{ }^{(i)}\right)$ is usually discontinued $24-48 \mathrm{~h}$ before and after injection with the radioligand ${ }^{111}$ In-pentetreotide ( $\left[{ }^{111}\right.$ In-DTPA $\left.{ }^{\circ}\right]$ octreotide) (Octreoscan ${ }^{(\mathbb{B})}$ ) because octreotide competes with radioligand for the same receptors. However, Dörr et al. and Soresi et al. reported improved visualization of carcinoid and small cell lung cancer lesions, respectively, during continued octreotide treatment. We found that intravenous administration of unlabeled octreotide to rats inhibited the binding of an optimal dose $(0.5 \mu \mathrm{g})$ of ${ }^{111}$ In-pentetreotide to somatostatin receptors in pancreas and adrenals in a mass- and time-dependent way. Pretreatment with unlabeled octreotide never increased receptor binding of ${ }^{111}$ In-pentetreotide. Administration of $100 \mu \mathrm{g}$ of octreotide decreased receptor-bound radioactivity if given simultaneously with or 10 or 20 min after injection of the radioligand, but had no effect if given $30 \mathrm{~min}$ after the radioligand. These findings indicate rapid processing of receptor-bound octreotide and suggest that octreotide treatment of patients undergoing ${ }^{111}$ In-pentetreotide scintigraphy may be reinitiated as soon as $1 \mathrm{~h}$ after radioligand administration. NUCL MED BIOL 24;8:749-753, 1997. (C) 1997 Elsevier Science Inc.
\end{abstract}

KEY WORDS. Octreotide, Somatostatin, Receptor Scintigraphy, ${ }^{111}$ In-Pentetreotide, Pharmacokinetics

\section{INTRODUCTION}

Regarding the tissue distribution of ${ }^{111}$ In-pentetreotide ([ ${ }^{111} \mathrm{In}$ DTPA $^{\circ}$ ]octreotide) (Octreoscan ${ }^{\circledR}$ ) in rats, we recently reported that the percentage uptake of radioactivity in somatostatin receptorpositive tissues is a bell-shaped function of the injected mass of pentetreotide, with an optimum between $0.5-5 \mu \mathrm{g}$ depending on the organ (3). In in vitro experiments with somatostatin receptorpositive pituitary cells, we found a rapid increase in the internalization of $\left[{ }^{125} \mathrm{~L}-\mathrm{Tyr}^{3}\right]$ octreotide by co-incubation with nanomolar concentrations of unlabeled octreotide (11). Because membrane binding was simultaneously increased, this effect may be related to a rapid recruitment of somatostatin receptors to the cell surface. We reported that an increase in specific activity of the radioligand did not increase the percentage uptake of radioactivity, nor the tatio between the uptake in somatostatin receptor-positive tissues and background (3). We found that priming with varying amounts of different somatostatin analogues at several time points relative to the injection of the radioligand significantly altered the percentage uptake of radioactivity in somatostatin receptor-positive tissues in rats (3). Since the conditions for peptide receptor scintigraphy or radionuclide therapy, resulting in the highest uptake of ${ }^{111} \mathrm{In}$ pentetreotide in target organs and optimal target to background ratios, have not yet fully been explored $(2-4,11,14)$, we investigated the pharmacokinetic aspects of the mode of administration of the radioligand. Because in in vitro studies an increase in the number of pancrcatic somatostatin receptors during incubation with glucose has been reported $(7-9,19)$ and because octreotide may increase

*Address correspondence to: W. A. P. Breeman, Ph.D., University Hospital "Dijkzigt," Department of Nuclear Medicine, Dr. Molewaterplein 40, 3015 GD Rorterdam, The Netherlands; e-mail: breeman@nuge.azr.nl.

Accepted 14 July 1997. blood glucose concentration (12), we also studied the effects of glucose injection prior to the radioligand on the uptake of radioactivity in somatostatin receptor-positive and receptor-negative tissues.

\section{MATERIALS AND METHODS Experimental Design}

${ }^{111}$ In-pentetreotide was prepared as previously described $(1,3)$. Pentetreotide ([DTPA ${ }^{\circ}$ loctreotide) was a gift of Mallinckrodt Medical, Petten, The Netherlands. Octreotide was a gift of Sandoz Pharma Ltd., Preclinical Research, Basel, Switzerland. Male Wistar rats $(240-260 \mathrm{~g})$ were anaesthetized with ether, and $3 \mathrm{MBq}(0.5$ $\mu \mathrm{g})$ of ${ }^{111}$ In-pentetreotide and/or additional peptides in $0.5-1 \mathrm{~mL}$ saline were injected into the dorsal vein of the penis. The rats were sacrificed $24 \mathrm{~h}$ after administration of radioligand. Blood was collected, and the pituitary gland, adrenals, colon, fundus, antrum, pancreas, kidneys, spleen, liver and femur muscle were isolated.

Radioactivity was determined in the injected fluid, tissue and blood through the use of a well-type scintillation counter LKB-1282 Compu- $\gamma$-system (1-3). The percentage of the injected radioactive dose (\%ID) per gram of tissue was calculated, as well as its ratio versus blood. Where appropriate, the \%ID uptake per gram of tissue in treated rats was expressed as a percentage of that in control animals. The experiments were approved by the Animal Welfare Committee (DEC) of Erasmus University.

EXPERIMENT A. Twelve groups of three rats each were injected with 2 or $10 \mu \mathrm{g}$ of octreotide at $-10,0,10$ and $20 \mathrm{~min}$ or with 100 $\mu \mathrm{g}$ of octreotide at $0,10,20$ and $30 \mathrm{~min}$ relative to the injection of $3 \mathrm{MBq}(0.5 \mu \mathrm{g})$ of ${ }^{111}$ In-pentetreotide. A group of six rats injected with radioligand only was used as controls. 


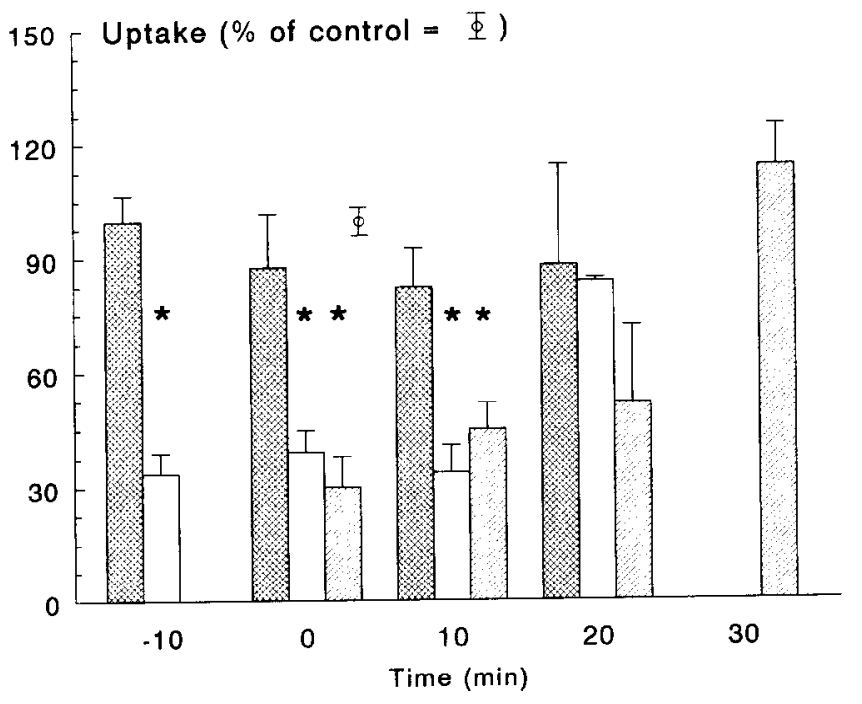

FIG. 1. Effects of i.v. administration of 2, 10 or $100 \mu \mathrm{g}$ of octreotide at indicated time intervals relative to the injection of $3 \mathrm{MBq}(0.5 \mu \mathrm{g})$ of ${ }^{111} \mathrm{In}$-pentetreotide on the $24 \mathrm{~h}$ uptake of radioactivity in the pancreas. Values are expressed as \%ID per gram of tissue relative to that in control rats $(100 \%) .{ }^{*} p<$ 0.05 versus control. Cross-hatched bars, $2 \mu \mathrm{g}$ of octreotide i.v.; open bars, $10 \mu \mathrm{g}$ of octreotide i.v.; hatched bars, $100 \mu \mathrm{g}$ of octreotide i.v.

EXPERIMENT B. Three groups of three rats each were injected with 10 or $100 \mu \mathrm{g}$ of octreotide or vehicle (controls) $4 \mathrm{~h}$ before the injection of $3 \mathrm{MBq}(0.5 \mu \mathrm{g})$ of ${ }^{111}$ In-pentetreotide.

EXPERIMENT C. Two groups of three rats each were injected with $0.5 \mu \mathrm{g}$ of pentetreotide 5 or $10 \mathrm{~min}$ before the injection of $3 \mathrm{MBq}$ $(0.5 \mu \mathrm{g})$ of ${ }^{111}$ In-pentetreotide, whereas a control group of three rats was injected with radioligand only.

EXPERIMENT D. Three groups of three rats each were injected once, twice or three times with $3 \mathrm{MBq}(0.5 \mu \mathrm{g})$ of ${ }^{111} \mathrm{In}$ pentetreotide at 30 -min intervals. The data are presented in thousand counts per minute per gram of tissue and as the percentage of the single or as the cumulated ID per gram of tissue.

EXPERIMENT E. Two groups of 3 rats each were injected with 0.5 $\mathrm{mL}$ of saline or a solution of $45 \mathrm{mg}$ of glucose in $0.5 \mathrm{~mL}$ of water 30 min before administration of $3 \mathrm{MBq}(0.5 \mu \mathrm{g})$ of ${ }^{111}$ In-pentetreotide.

\section{Statistical Analysis}

The data are presented as the means \pm SD. One-way analysis of variance (ANOVA) was used for statistical analysis. Means were compared using Bonferroni's t-test or the Newman-Keuls method (17). A $p$ value of $<0.05$ was considered significant.

\section{RESULTS}

The results of experiment $A$ (Figs. 1 and 2) show that administration of $100 \mu \mathrm{g}$ of octreotide together with or 10 or $20 \mathrm{~min}$ after injection of ${ }^{111}$ In-pentetreotide resulted in a significant inhibition of the \%ID uptake in pancreas and adrenals. No effect was obscrved if administration of $100 \mu \mathrm{g}$ of octreotide was delayed until $30 \mathrm{~min}$ after injection of radioligand. Administration of $10 \mu \mathrm{g}$ of octreotide $10 \mathrm{~min}$ before, together with or $10 \mathrm{~min}$ after injection of ${ }^{111} \mathrm{In}$ - pentetreotide also resulted in a significant inhibition of the uptake of radioligand in pancreas and adrenals. No effect was observed if 10 $\mu \mathrm{g}$ of octreotide was administered 20 or $30 \mathrm{~min}$ after the radioligand. Regardless of the time interval, administration of $2 \mu \mathrm{g}$ of unlabeled octreotide did not affect \%ID uptake of radioligand in the pancreas. Similar results were found in other octreotide receptorpositive tissues (pituitary, fundus, antrum and colon; data not shown). Under no condition was uptake of radioligand in octreotide receptor-negative tissues affected by administration of unlabeled octreotide (data not shown).

In experiment B, rats were pretreated with $100 \mu \mathrm{g}$ of octrcotide $4 \mathrm{~h}$ before the administration of radioligand. This resulted in a significantly lowered \%ID uptake in all somatostatin receptor-positive tissues, as shown for the adrenals and pancreas in Figure 3. The ratio of \%ID uptake in these tissues versus blood was also lowered (data not shown). Pretreatment with $10 \mu \mathrm{g}$ of octreotide $4 \mathrm{~h}$ prior to the radioligand also decreased uptake of ${ }^{111}$ In-pentetreotide in the pancreas, but not in adrenals (Fig. 3) or other tissues (data not shown).

In experiment $C$, priming with $0.5 \mu \mathrm{g}$ of pentetreotide 5 or 10 min prior to the radioligand significantly increased the \%ID per gram of pancreas from $0.61 \pm 0.02$ to $0.97 \pm 0.06$ and $1.10 \pm 0.07$, respectively (Fig. 4). No significant alterations were observed in other tissues (data not shown).

In experiment $\mathrm{D}$, multiple injections of $3 \mathrm{MBq}(0.5 \mu \mathrm{g})$ of ${ }^{111}$ In-pentetreotide resulted in a proportional increase in the absolute uptake of radioactivity in the somatostatin receptornegative and receptor-positive tissues, as shown for the kidney and pancreas, respectively (Fig. 5). However, multiple injections of radioligand did not change the percent cumulated ID uptake in the different tissues compared with a single injection (data not shown).

In experiment $E$, injection of $45 \mathrm{mg}$ of glucose $30 \mathrm{~min}$ before the administration of the radioligand did not change the \%ID uptake in somatostatin receptor-positive and receptor-negative tissues (Fig. 6).

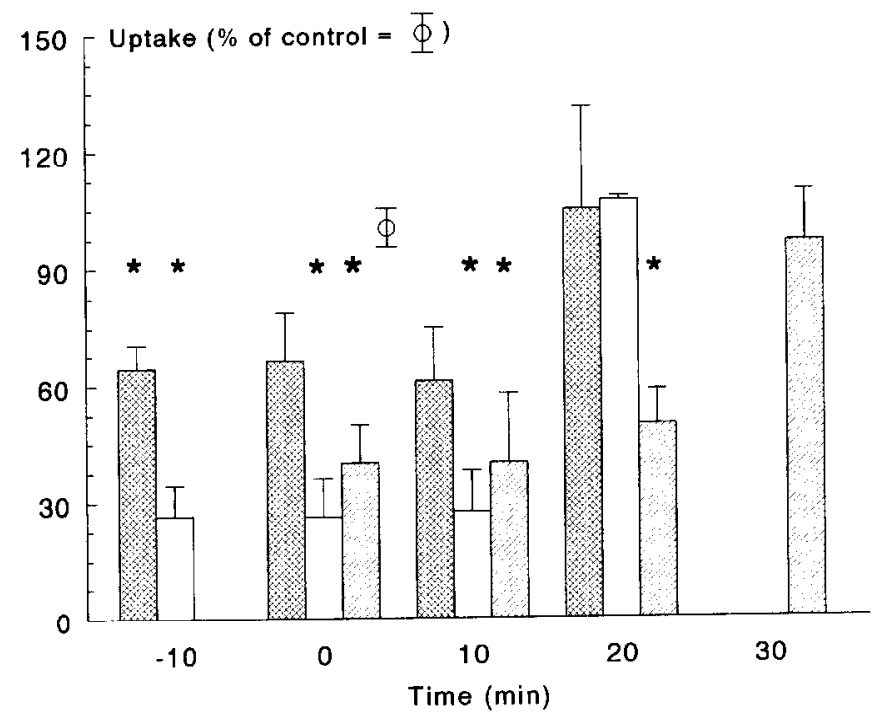

FIG. 2. Effects of i.v. administration of 2,10 or $100 \mu \mathrm{g}$ of octreotide at indicated time intervals relative to the injection of $3 \mathrm{MBq}(0.5 \mu \mathrm{g})$ of ${ }^{111}$ In-pentetreotide on the $24 \mathrm{~h}$ uptake of radioactivity in the adrenals. Values are expressed as \%ID per gram of tissue relative to that in control rats $(100 \%) .{ }^{*} p<$ 0.05 versus control. Cross-hatched bars, $2 \mu \mathrm{g}$ of octreotide i.v.; open bars, $10 \mu \mathrm{g}$ of octreotide i.v.; hatched bars, $100 \mu \mathrm{g}$ of octreotide i.v. 


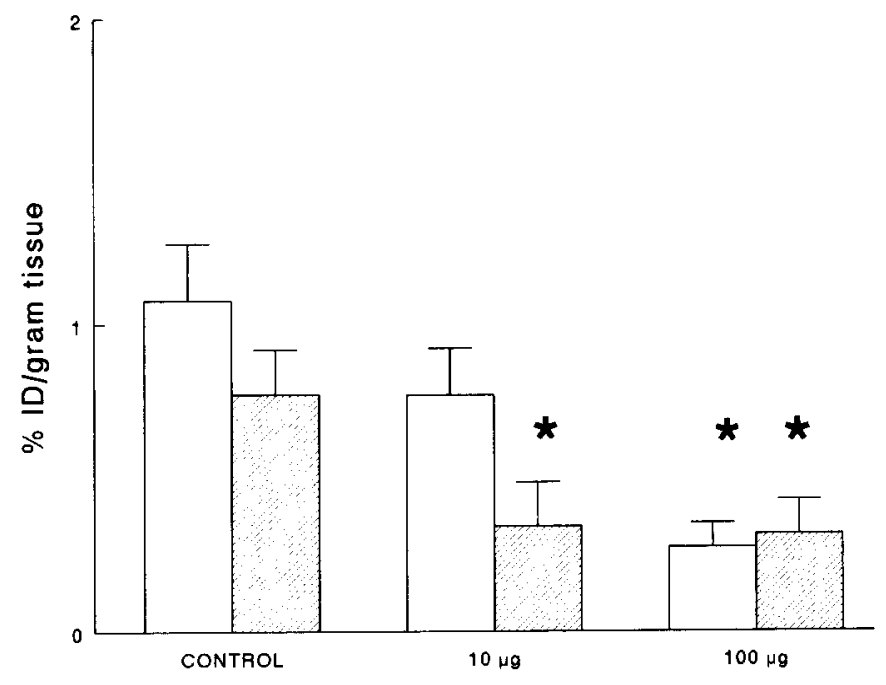

FIG. 3. Effects of i.v. administration of 10 or $100 \mu \mathrm{g}$ of octreotide $4 \mathrm{~h}$ before administration of the radioligand on the $24 \mathrm{~h}$ uptake of radioactivity in adrenals and pancreas, expressed as the \%ID per gram of tissue. ${ }^{*} p<0.05$ versus control. Open bars, adrenals; hatched bars, pancreas.

\section{DISCUSSION}

Dörr et al. $(5,6)$ and Soresi et al. (18) reported improved visualizarion of tumors in patients with ${ }^{111}$ In-pentetreotide during continued octreotide treatment. They showed that the uptake of ${ }^{111}$ In-pentetreotide in spleen, kidneys and liver is lowered during treatment with $200 \mu \mathrm{g}$ of octreotide subcutaneously (s.c.) three times per day, resulting in an increased target-to-background ratio.

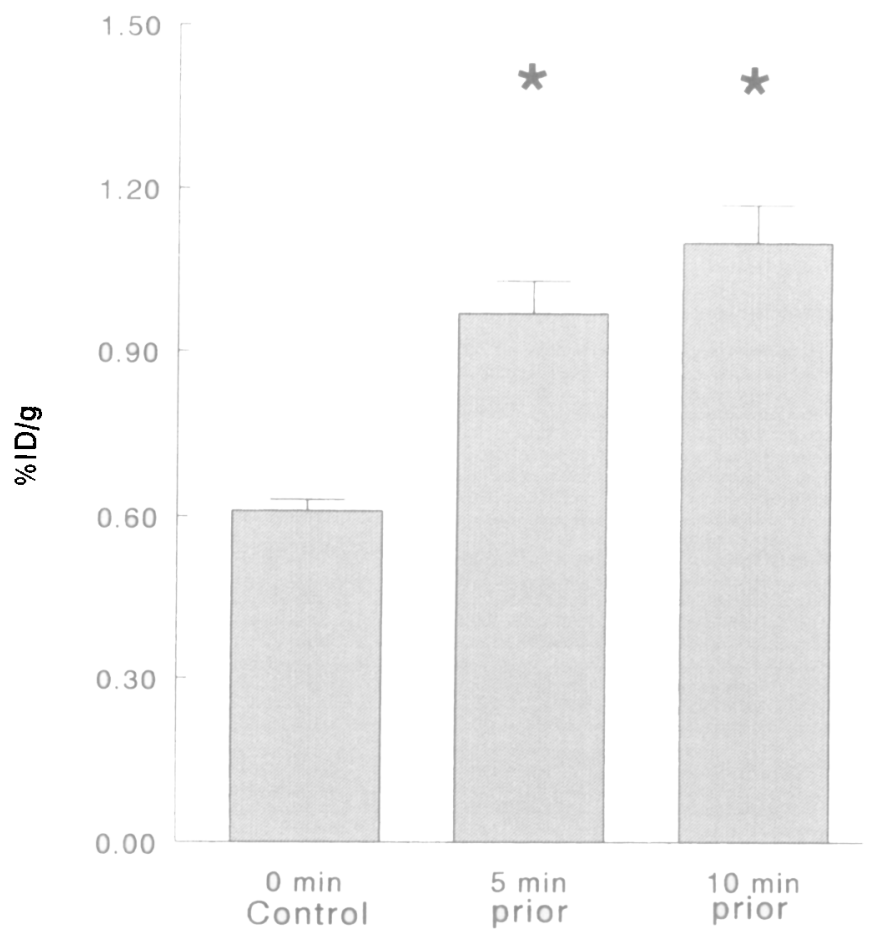

FIG. 4. Effects of i.v. injection of $0.5 \mu \mathrm{g}$ of pentetreotide at 5 or $10 \mathrm{~min}$ prior to the administration of ${ }^{111}$ In-pentetreotide on the $\mathbf{2 4} \mathrm{h}$ uptake of radioactivity in the pancreas, expressed as \%ID per gram of tissue. ${ }^{*} p<0.05$ versus control.

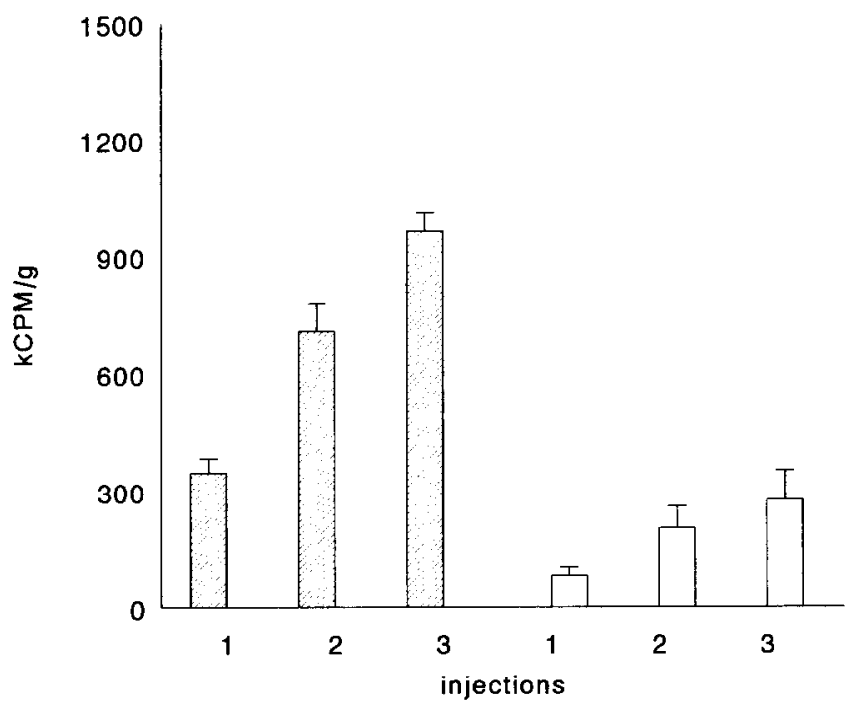

FIG. 5. Effects of multiple injections of ${ }^{111}$ In-pentetreotide on the $24 \mathrm{~h}$ uptake of radioactivity in the pancreas and the kidneys, expressed per gram of tissue. Hatched bars, kidneys; open bars, pancreas.

We have also found a markedly decreased uptake of ${ }^{11}$ In-pentetreotide in spleen in patients treated with octreotide (13). However, it is unclear whether the improved visualization of tumors by ${ }^{111}$ In-pentetreotide during continued octreotide treatment is only due to reduced background or whether this is also associated with an increased accumulation of radioligand in the somatostatin receptorpositive tissues (priming). We therefore undertook the present study in rats to address this question.

In experiments $A$ and $B$, it was shown that the administration of

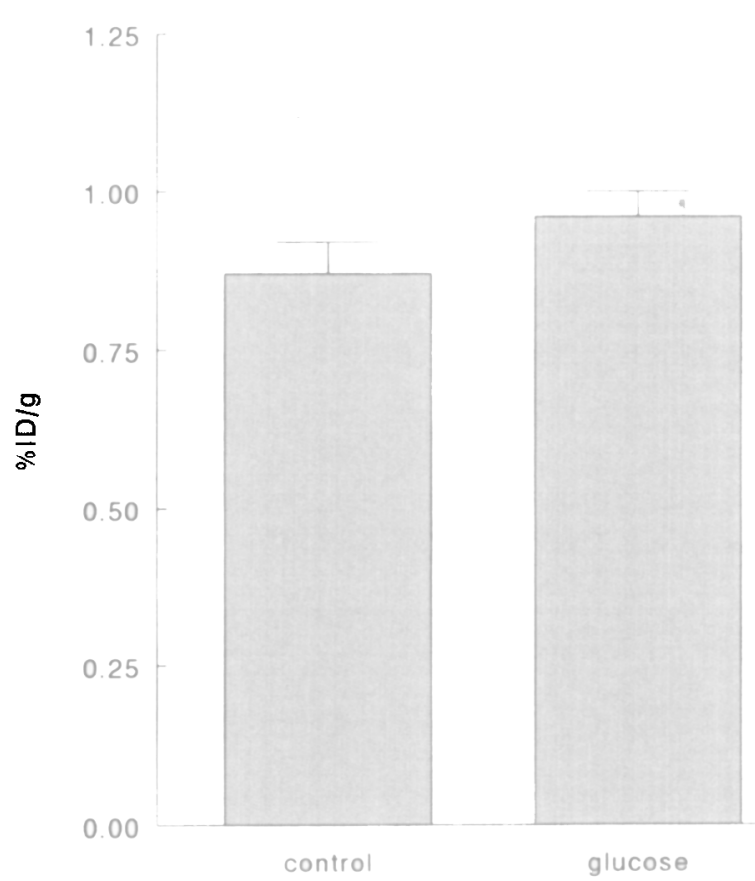

FIG. 6. Effects of pretreatment with $45 \mathrm{mg}$ of glucose $30 \mathrm{~min}$ before the administration of ${ }^{11}$ In-pentetreotide on the $24 \mathrm{~h}$ uptake of radioactivity in the pancreas, expressed as \%ID per gram of tissue. 
different amounts of octreotide at different timepoints relative to the injection of ${ }^{111}$ In-pentetreotide may significantly alter the \%ID of uptake in a mass- and time-dependent way. Administration of $100 \mu \mathrm{g}$ of octreotide results in a marked inhibition of the uptake of $0.5 \mu \mathrm{g}$ of ${ }^{111}$ In-pentetreotide in the octreotide receptor-positive tissues if given between $4 \mathrm{~h}$ before and $20 \mathrm{~min}$ after injection of ${ }^{111}$ In-pentetreotide, but not if this is delayed until $30 \mathrm{~min}$ after radioligand injection. Similar findings were obtained with administration of $10 \mu \mathrm{g}$ of octreotide, although if given $4 \mathrm{~h}$ before the radioligand, it produced only a significant decrease radioligand uptake in the pancreas and was already without effect on uptake of radioactivity in any tissue if given $20 \mathrm{~min}$ after radioligand. Regardless of the time interval, administration of $2 \mu \mathrm{g}$ of octreotide did not significantly affect tissue distribution of ${ }^{111}$ In-pentetreotide. Under no condition was uptake of radioligand in any somatostatin receptor-positive or receptor-negative tissue significantly stimulated by pretreatment with unlabeled octreotide (priming). It should be pointed out that the mass of injected radioligand $(0.5 \mu \mathrm{g})$ has previously been shown to result in near-optimal uptake in the pancreas and optimal uptake in the other octreotide receptorpositive tissues adrenals and pituitary (3).

In experiment $C$, priming with $0.5 \mu \mathrm{g}$ of pentetreotide 5 or 10 min prior to the radioligand resulted in a higher \%ID uptake in the pancreas, but not in other tissues. However, it is not excluded that administration of $1 \mu \mathrm{g}$ instead of $0.5 \mu \mathrm{g}$ of ${ }^{111} \mathrm{In}$-pentetreotide would also have resulted in an increased \% ID uptake in the pancreas. The results of experiment $\mathrm{D}$, involving multiple-dose injections, indicate that priming effects are not observed if the interval between the injections of $0.5 \mu \mathrm{g}$ of ${ }^{111}$ In-pentetreotide is increased to $30 \mathrm{~min}$.

In many respects, the experiments performed in the present study are not comparable with the situation in patients undergoing ${ }^{111}$ In-pentetreotide scintigraphy while on octreotide therapy. First, in contrast with the chronic treatment of these patients with octreotide, we have only studied the acute effects of octreotide administration on uptake of radioligand, with the longest interval only $4 \mathrm{~h}$. Second, octreotide therapy is given to patients by s.c. injections, whereas we studied the effects of intravenous (i.v.) injections of unlabeled octreotide on tissue uptake of the radioligand. Third, whereas the success of ${ }^{11}$ 'In-pentetreotide scintigraphy in the detection of lesions in patients depends on the uptake of radioligand in lesions versus surrounding tissues, we concentrated in this study on the changes in uptake on octreotide receptor-positive tissues versus receptor-negative tissues. Fourth, the present study in rats was conducted by administration of a dose $(0.5 \mu \mathrm{g}, 3 \mathrm{MBq})$ of ${ }^{111}$ In-pentetreotide that is optimal for uptake in normal octreotide receptor-expressing tissues in rats, whereas the optimal dose of this radioligand has not been determined with certainty in patients and may actually vary for different lesions. However, preliminary data in patients indicate that when a standard dose of $220 \mathrm{MBq}$ of ${ }^{111} \mathrm{In}$ is coupled to less than $5 \mu \mathrm{g}$ of the ligand [DTPA ${ }^{\circ}$ ]octreotide, this will lead to a decreased quality of scintigraphy and that uptake in tumors is significantly reduced (14).

Previous studies have made clear that the interaction of radiolabeled octreotide with the octreotide receptor is not a static process governed only by the law of mass action, but depends on a variety of mostly dynamic factors, including (i) the affinities, association and dissociation rates of labeled and unlabeled [DTPA ${ }^{\circ}$ ]octreotide for the octreutide receptors (i.e., type 2 and type 5 somatostatin receptors); (ii) competition with endogenous somatostatin; (iii) competition with residual, circulating octreotide; (iv) different rates of internalization of the labeled and unlabeled ligand-receptor complex in different tissues/tumors; (v) induction of the internalization of the octreotide receptor by octreotide pretreatment (downregulation) in some tissues/tumors; (vi) stimulation of cell surface exposure of octreotide receptors via recruitment of intracellular receptors or increased receptor synthesis by octreotide pretreatment (up-regulation) in other tissues/tumors; (vii) residence times of the radionuclide in the different tissues/tumors; (viii) accessibility of octreotide receptors in different tissues/tumors for circulating labeled and unlabeled octreotide; (ix) pharmacokinetics and metabolism of labeled and unlabeled octreotide, etc.

It is clear from the above that it is impossible to predict how long before administration of the radioligand the treatment of patients with octreotide should be stopped. If only the law of mass action applies, sufficient time should elapse since the last s.c. injection of unlabeled octreotide to allow its disappearance from the circulation to levels insufficient for competition with radioligand for the octreotide receptor. After s.c. administration to human subjects, circulating octreotide shows a half-life of $110 \mathrm{~min}$, an apparent distribution volume of 29.4 liters, and metabolic clearance rate of $172 \mathrm{~mL} / \mathrm{min}(10,16)$. A lag time of $4-8$ half-lives $(7.5-15 \mathrm{~h})$ after the last octreotide treatment may then be sufficient to prevent interference with receptor binding of injected radioligand.

However, these considerations completely ignore possibly positive effects of octreotide pretreatment on subsequent accumulation of labeled octreotide in tumors via stimulation of receptor expression or receptor-ligand internalization. The optimal time interval between the administration of the last dose of unlabeled octreotide and the radioligand, therefore, needs to be determined empirically. Our results do indicate, however, that octreotide therapy may be reinitiated very soon after administration of the radioligand. Leners et al. (15) recently reported no effect on the \%ID uptake in somatostatin receptor-positive and receptor-negative targets in patients by i.v. administration of $50 \mu \mathrm{g}$ of octreotide $24 \mathrm{~h}$ after the radioligand. We have also found that reinitiation of octreotide therapy $6 \mathrm{~h}$ after administration of radioligand does not affect the percentage uptake of radioactivity in tumor lesions (unpublished data). Our results in rats suggest that this period may be further shortened to $1 \mathrm{~h}$.

It has been shown that octreotide administration increases the blood glucose concentration (12), which in turn may increase the expression of somatostatin receptors in the pancreas $(7-9,19)$. This represent a potential indirect mechanism for the homologous up-regulation of octreotide receptor expression in the pancreas. We found that pretreatment of rats with glucose did not affect the uptake of an optimal dose of ${ }^{111} \mathrm{In}$-pentetreotide in the pancreas. However, much like the effects of pretreatment with unlabeled octreotide, it is not excluded that glucose "priming" may stimulate the uptake of a suboptimal dose of radioligand.

In conclusion, priming of rats with different amounts of octreotide or pentetreotide at different time intervals does not increase the \%ID uptake of an optimal dose $(3 \mathrm{MBq}, 0.5 \mu \mathrm{g})$ of ${ }^{111} \mathrm{In}$ pentelteutide in somatustatin receptor-positive tissues, and administration of large amounts of octreotide $30 \mathrm{~min}$ after the radioligand does not influence the \%ID uptake of radioligand in somatostatin receptor-positive tissues.

The authors wish to thank Arthur van Gameren, Eric van den Berg and Thijs van Aken for their expert assistance during the experiments. 


\section{References}

1. Bakker W. H., Alberts R., Bruns C., Breeman W. A. P., Hofland L. J., Marbach P., Pless L., Pralet D., Stolz B., Koper J. W., Lamberts S. W. J., Visser T. J. and Krenning E. P. (1991) [ ${ }^{111}$ In-DTPA-D-Phe ${ }^{1}$ octreotide, a potential radiopharmaceutical for imaging of somatostatin receptorpositive tumors: Synthesis, radiolabeling and in vitro validation. Life Sci. 49, 1583-1591.

2. Breeman W. A. P., Hofland L. J., van der Pluijm M., van Koetsveld P. M., de Jong M., Setyono-Han B., Bakker W. H., Kwekkeboom D. J., Visser T. J., Lamberts S. W. J. and Krenning E. P. (1994) A new radiolabeled somatostatin analogue $\left[{ }^{111}\right.$ In-DTPA-D-Phe $\left.{ }^{1}\right]$ RC-160: Preparation, biological activity, receptor scintigraphy in rats and comparison with [ [" In-DTPA-D.Phe ${ }^{1}$ octreotide. Eur. J. Nucl. Med. 21, 328--335.

3. Breeman W. A. P., Kwekkeboom D. J., Kooij P. P. M., Bakker W. H., Hofland L. J., Visser T. J., Ensing G. J., Lamberts S. W. J. and Krenning E. P. (1995) Effect of dose and specific activity on tissue distribution of indium-111-pentetreotide in rats. J. Nucl. Med. 36, 623-627.

4. Breeman W. A. P., Bakker W. H., de Jong M., Hofland L. J., Kwekkeboon D. J., Kooij P. P. M., Visser T. J. and Krenting E. P. (1996) Studies on radiolabeled somatostatin analogues in rats and in patients. Quart. J. Nucl. Med. 40, 209-220.

5. Dörr U., Wurm K., Höring E., Guzman G., Räth U. and Bihl H. (1992) Diagnostic reliability of somatostatin receptor scintigraphy during continuous treatment with different somatostatin analogs. Horm. Metab. Res. $27,36-43$.

6. Dörr U., Räth U., Sautter-Bihl M.-L., Guzman G., Bach D. and Adrian H.-J. (1993) Improved visualization of carcinoid liver metastases by indium-111 pentetreotide scintigraphy following treatment with cold somatostatin analogue. Eur. J. Nucl. Med. 20, 431-433.

7. Draznin B., Leitner ]. W. and Sussman K. E. (1982) Kinetics of somatostatin receptor migration in isolated pancreatic islets. Diabetes $31,467-469$

8. Draznin B., Leitner J. W. and Sussman K. E. (1985) A unique control mechanism in the regulation of insulin secretion: Secretagogue-induced somatostatin receptor recruitment. J. Clin. Invest. 75, 1510-1516.

9. Draznin B., Sherman N., Sussman K. E., Dahl R. and Vatter A. (1985) Internalization and cellular processing of somatostatin in primary culture of rat anterior pituitary cells. Endocrinology 117, 960-966.
10. Harris A. G. (1994) Somatostatin and somatostatin analogues: Pharmacokinetics and pharmacodynamic effects [review]. Gut 35, S1-S4.

11. Hofland L. J., van Koetsveld P. M., Waaijers M., Zuyderwijk J., Breeman W. A. P. and Lamberts S. W. J. (1995) Internalization of the radioiodinated somatostatin analogue, $\left.\left[{ }^{125}\right]-T_{y r}{ }^{3}\right]$ octreotide, by mouse and human pituitary tumor cells: Increase by unlabeled octreotide. Endocrinology 136, 3698-3706.

12. Ikebuchi M., Suzuki M., Kageyama A., Hirose J., Yokota C., Ikeda K., Shinozaki K., Todo R. and Harano Y. (1996) Modified method using a somatostatin analogue, octreotide acetate (Sandostatin), to assess in vivo insulin. Endocr. J. 43, 125-130.

13. Krenning E. P., Kwekkeboom D. J., Bakker W. H., Breeman W. A. P., Kooij P. P. M., Oei H. Y., van Hagen M., Postema P. T. E., de Jong M., Reubi J. C., Visser T. J., Reijs A. E. M., Hofland L. J., Koper J. W. and Lamberts S. W. J. (1993) Somatostatin receptor scintigraphy with $\left[{ }^{111}\right.$ In-DTPA-D-Phe $\left.{ }^{1}\right]$ - and $\left[{ }^{123}\left[-\mathrm{Tyr}^{3}\right]\right.$ octreotide: The Rotterdam experience with more than 1000 patients. Eur. J. Nucl. Med. 20, 716-731.

14. Kooij P. P. M., Kwekkeboom D. J., Breeman W. A. P., Reijs A. E. M., Bakker W. H., Lamberts S. W. J., Visser T. J. and Krenning E. P. (1994) The effects of specific activity on tissue distribution of $\left[^{111} \ln\right.$-DTPA-DPhe ${ }^{1}$ loctreotide in humans. J. Nucl. Med. 35, 1-226.

15. Leners N., Jamar F., Fiasse R., Ferrant A. and Pauwels S. (1996) Indium-111-pentetreotide in endocrine tumors and lymphoma. J. Nucl. Med. 37, 916-922.

16. Nicholls J., Wynick D., Domin J., Sandler L. M. and Bloom S. R. (1990) Pharmacokinetics of the long-acting somatostatin analogue octreotide (SMS 201-995) in acromegaly. Clin. Endocrinol. 32, 545-550.

17. Snedecor G. W. and Cochran W. G. (1980) Statistical Methods, 7th edn. Iowa State University Press, Ames.

18. Soresi E., Bombardieri E., Chiti A., Boffi R., Invernizzi G., Crippa F. and Maffioli L. (1995) In-111-DTPA-octreotide scintigraphy modulation by treatment with unlabelled somatostatin analogue in small-cell lung cancer. Tumori 81, 125-127.

19. Sussman K. E., Pollard H. B., Leitner J. W., Nesher R., Adler J. and Cerasi E. (1982) Granule fusion and fission (discharge) are biochemically events of exocytotic hormone release. Trans. Assoc. Am. Physicians 95, 299-303. 